InVisible Culture • Issue 31: Black Studies Now and the CounterCurrents of Hazel Carby

\title{
Knowing Yourself, Historically: An Interview with Hazel Carby
}

Joel Burges ${ }^{1}$, Jerome Dent ${ }^{2}$, Alisa V. Prince ${ }^{3}$, Patrick Sullivan', Jeffrey Allen Tucker ${ }^{1}$, Hazel Carby ${ }^{4}$, Clara Auclair, Byron Fong ${ }^{1}$, Peter Murphy, Kendall DeBoer

${ }^{1}$ University of Rochester, ${ }^{2}$ Tulane University, ${ }^{3}$ Northeastern University, ${ }^{4}$ Yale

Published on: Nov 15, 2020

DOI: $10.47761 / 494 \mathrm{a} 02 \mathrm{f} 6.6 \mathrm{f} 1 \mathrm{a} 018 \mathrm{a}$

License: Creative Commons Attribution 4.0 International License (CC-BY 4.0). 


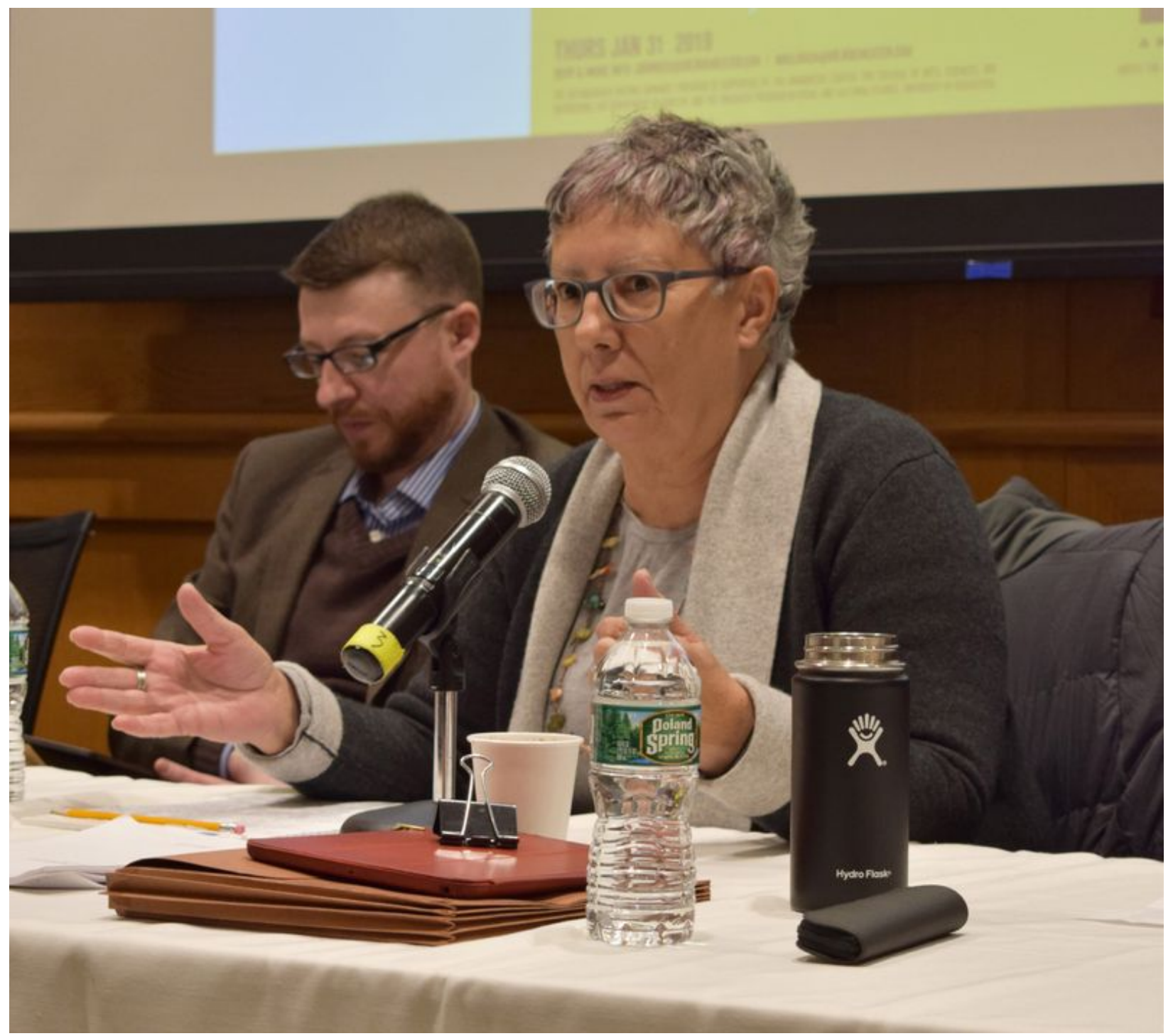

Hazel Carby was the University of Rochester's 2018/2019 Distinguished Visiting Humanist. Since 2012, the Distinguished Visiting Humanist program has brought scholars and artists to campus for three to four days in activities that are both academic and public. This interview took place on the last day of Hazel Carby's visit to University of Rochester in February_of 2019, closing three days of formidable exchanges between Professor Carby and the Rochester community. During this threehour discussion, graduate students and faculty from the university's English Department and Graduate Program in Visual and Cultural Studies engaged Professor 
Carby on her latest work, Imperial Intimacies, asking what inspired her to approach British imperialism through autobiographical writing, or what she calls "auto history."

The conversation centers on Carby's imperative to think about ourselves as historical subjects. To trace this theme in her body of work, the interview covers her career trajectory from the United Kingdom to the United States, as she developed foundational work in the field of cultural studies and the study of black diaspora. The conversation then moves to urgent questions of antiracism and the future of African American Studies in US academia. Publishing this interview in the Fall of 2020 only reinforces its pertinence, as the US and the world at large grapple with issues of social and environmental justice, two questions at the heart of this issue and Carby's latest work.

Interview edited by Clara Auclair and Byron Fong. Annotations by Kendall DeBoer and Peter Murphy.

Alisa Prince: Let's begin by talking about where you are now and where you've been, both intellectually and institutionally. Your career has quite a range, but I think there's the consistency of thinking about where people are in their historically specific moment relative to their material conditions, and how people live through the contradictions that arise at that juncture. So I'm thinking about your latest project, Imperial Intimacies, where you're grappling with your personal relationship to the archive to tell not just a family story, but a broader story of empire, and how you get to somewhere like that from a book like Reconstructing Womanhood. 1 So can you talk about the trajectory of your career between those two?

Hazel Carby: I don't think I'm asking the same questions that I thought I was asking in something like Reconstructing Womanhood, but I do feel that what I'm doing now is informed by all the previous work. I'm definitely now trying to take all the theoretical work and commitment to the politics and understanding of a historical formation, but I'm also trying to write in a different voice. Reconstructing Womanhood really comes out of the PhD that I was doing at the Centre for Contemporary Cultural Studies, and a dissertation proposal that people told me I couldn't do because there weren't any black women writers. $\underline{2}$ So at the time I had to respond to that question. On the UK side of it, I actually haunted the library of the British Museum. I sort of semi-lived in it. I was excavating the narratives by women who had been enslaved and had written their stories. The abolitionist movement published a lot of that stuff in Britain. First. Even 
before the US. So I had access to this material that I thought sort of proved everybody wrong, if you like.

On a visit to Yale, I met Charles Davis, who was then the head of African-American studies at Yale and was the most extraordinary intellectual. $\underline{3}$ He was just incredible. I met him at a Yale English department party one December, and he said, "I hear that you're doing all this stuff in the British library on slave narratives. Why don't you come here?" They had a situation where you could be a special student, so you could actually bring your funding with you. I brought my grants and everything from the UK, but I was writing at Yale with him. And I worked with John Blassingame and Robert Stepto. $\underline{4}$

I met Skip Gates there who asked me a question that completely stunned me. $\underline{5}$ And his question was, "Why is a nice young white lady like you working on black women writers?" And I was just sort of speechless. I didn't quite know what to say. And I began to think, "This is not Europe." I actually began to think back to what I knew theoretically, that race is not the same in these different places, and I began to think in a sort of critical way about these various inscriptions on the body. And then the other thing that quite stunned me was that people would say, "Why do you keep using this term 'diaspora?'”

I started to think very critically about the way in which African American studies here was very nationalist bound. It was developing very interesting histories of enslavement, but taking absolutely no notice of what was happening in the Caribbean and Brazil. So there was a lot of the perspective that I had taken from growing up in Britain, where you were in this incredibly diasporic situation. You were working always with African intellectuals and students and Caribbeans-I mean from colonies all over the world. You just had a completely different perspective, really, on questions of colonization. Then I moved to a situation where "the colonial" meant British rule but only in North America or something. So I realized that there was a very different audience and context to speak to.

At first, I imagined that I was always going to go back to the UK. But when I came here, Maggie Thatcher was still prime minister, and Maggie Thatcher was not having any of that black power stuff in Britain. $\underline{6}$ Institutionally what that meant was, for example, the grants I had, which were from the government but that you could take to whichever institution you wanted, were stopped. You had to go to an approved place. But what it also meant was that I couldn't get an academic job [in the UK], so I ended up getting a job at Wesleyan. 
I found myself engaging with John Blassingame's work. He was in fact incredibly supportive, but I had this whole critique of the way in which he really only looked at slave narratives by men as a source. He had mounted this incredible battle within the American Historical Association, because they would not take slave narratives as legitimate sources for history. Basically, they would only use plantation records. They would even use planters' diaries and stuff, but they said that slave narratives were too partial. They weren't distant enough from history. They were not objective.

So he'd mounted this huge battle, and he'd written this slave community book, which was quite astonishing. And then in the classroom, when I was mounting my case for thinking about slave narratives by women, he said, "Well, they're actually too literary. They use these tropes. They read like sentimental novels." And I [thought], okay, so I know what I need to say about all this. That structured a particular direction for engaging African American studies.

The other major issues that emerged that relates to the question of "Why are you always talking about diaspora?" is that getting the job at Wesleyan and also having sort of taught at Yale, I began to understand the intellectual formation and people began to get to know me, and there was actually quite a lot of resentment about occupying positions in African American studies at that point, having come from Britain and being of Brazilian heritage, as opposed to having been born here. I had to understand the institutional formation in which I was working. The field was being fought over in a way where it actually became extremely important that there were certain bodies who were teaching it. It was a way to actually get black people into the academy, except that it was really quite parochial in that the field itself became, not exactly competitive, but there were so few positions in the academy that there was a lot invested in positions that were opening up actually going to African Americans. So I realized there was some antagonism that wasn't really about work, although it was in some ways about the different perspective-the diasporic as opposed to the nationalbut that I also was taking up space that could have gone to somebody who was actually African American. And I had to understand it historically, in a way that was very different to how those of West Indian heritage were perceived in Britain and in Europe. So I had to understand that context. But it didn't make it very easy. There were times when I felt quite isolated, and that's where Charles Davis and John Blassingame were very important, although Charles Davis died soon afterwards. But I had to think very carefully about how I positioned myself. In this place, as well as being completely ethically and morally and politically true to what I believe. I had to tread very, very carefully. And that doesn't come very naturally to me, because I tend to be outspoken. 
But there was quite a lot of antagonism that I had to face. And that surfaced again when Reconstructing Womanhood came out. Because it's like, "Who is this upstart?" But at that point it wasn't just me, because things we were publishing in Britain were beginning to come out. Isaac [Julien] was staying with us at one point and was here to do things. $\underline{7}$ So there was this moment of, "Is black British cultural studies taking over?", as if we were in this competitive position, which was a shame because we were all actually in pretty vulnerable positions. $\underline{8}$ So I was not terribly comfortable. And I wasn't necessarily thought to be "at home" in African American studies. And so I realized that actually what I was going to have to do was just commit to its theoretical expansion and its political expansion. Which is what I've always done. You know, pushing the boundaries for the Americas, plural. And for a diasporic perspective. That's how I was sort of shaped then. So you can see there are some threads that remain, but a lot of that had to be built out of my presence here.

Prince: It gets me thinking about the tension between being at once included in something but also still being there and feeling excluded, which is one of the jumping off points for Reconstructing Womanhood, right? At the women of the Columbian exposition. $\underline{9}$

Carby: Yes.

Prince: And I was thinking about that tension coupled with this authentication of blackness. In Black Studies there's the hope that the work that you're doing will be validated in some way by other people in the field and other people who might read it. And I guess I'm curious about your thoughts on how you grappled with the struggle between the two.

Carby: I don't think an outsider perspective is actually necessarily a negative. I think one of the incidents that made me realize profoundly what was going on in the academy was to meet this black woman scholar who was a classicist. She went for an interview at Harvard for a job in classics, and they wanted her to teach African American studies, which she'd never been trained in. I mean it was just-she was literally there for this job in classics and the sort of horror of that made me understand in a way the politics of what I was facing.

One of the things I found when I'd finished Reconstructing Womanhood, even though I had that trope of the stage and the Chicago [Columbian] exposition and these black women entering this sort of space, was that I actually had ended with a very middleclass black perspective. I realized how limited that was, and in a way how far away 
that was from thinking about the women who'd actually written the slave narratives. At the time, I tried to include the perspective of the class tension that was emerging, and the way in which middle-class values were both a defense and a way of surviving. But it also meant that you then had a very difficult perspective on working-class black life and how black life needed to be transformed to be accepted. So that actually took me right to the blues women. And thinking about the urban context and blues in the black women's project and that sort of thing. $\frac{10}{}$ And thinking very critically about the way in which even those who were being subordinated can develop structures which then end up subordinating others.

Prince: Right. It's one of the consistencies [in your work], from the slave narratives to these middle class ideals, and then even the blues women that you talk about. You always foreground that black women are able to shape the conditions that they live within.

Carby: Oh, yeah.

Prince: That was one of the things I found really powerful.

Carby: Right. But, you know those conditions are also always overdetermined. So you're never actually practicing refusal, whether it's outside of the institution of slavery or whether it's in, you're never actually outside of the racial formation. But, yes, you do. You are always determining your conditions, but you're practicing revolution within these conditions that are already overdetermined by history.

Prince: When it comes to contemporary writers, black women writers in particular, do you feel like the work of reconstructing is something that always needs to be done retrospectively, looking back on the work of the women? Or is it something that we should be doing as we read these writers now, in the moment, thinking through their lives and the conditions that they're writing in?

Carby: Is it not both? Is it not really dialectical, in that there's this current moment that you're writing out of, and in a way that shapes what you're looking for in the past? And then the move is to try and understand those specific historical moments. But it's always about how one really informs another. And then trying to figure out what the difference in specificities are. You know in Britain, African women writers were asking really important questions about the colonial and how they were situated in the colonial. And nobody really could figure out- I think I used that phrase last night [at my talk]: "We are here because you are there." So even though those particular writers 
were not in the final work [of Reconstructing Womanhood], there is that sense that there was this racial formation here and that these black women were asking questions and that their lives were posing dilemmas that were not the same as black men or white women or whatever, that there was this really important perspective that was completely missing. And without which you couldn't actually refigure the whole. So it wasn't just that they were a part of a puzzle. The argument always was that without that perspective you really can't understand the whole. I thought I was maybe doing a better job at the end of Reconstructing Womanhood, thinking about the questions of race and gender. But I was taking less notice of the question of class, and that's why I really wanted to deal with the blues women. There had emerged all this work on the blues, which was becoming really formative in black music research. And it was giving a whole trajectory of a history. Right. But what was also in it was a rural story. And it was all men. $\frac{11}{}$ And they never took the women seriously, because they were being recorded in these urban spaces. It wasn't only about making sure these women were paid attention to, but really, their presence and their work meant that you had to reconfigure the way you would even imagine the history of the music as a form.

Prince: In Reconstructing Womanhood you say "black feminist criticism has too frequently been reduced to an experiential relationship that exists between black women as critics and black women writers who represent black women's realities. Theoretically this reliance on a common, or shared, experience is essentialist and ahistorical." How do we deal with the awareness of a dismissal of women's history, whether it be a set of shared experiences or certain things that we know to be true without coming to the work with any assumptions? For example, one of the things in Reconstructing Womanhood that struck me was that you're looking at how these different stories are haunting the contemporary women's moment, but still you come to each case without any assumptions about what might shape their position.

Carby: In a way that's what I meant by the fact that an outsider perspective is actually not always a bad thing, because you make the shift, not just from the UK to here, but from the whole way in which you actually imagine black culture and who's producing it. On the one hand, the international framework of it, and then moving into a field that was so committed to being bound by a nationalist perspective. So I already understood that there was a lot of work being done to shape a framework that would then force you to interpret whatever entered that framework in particular ways.

The question of looking at black women writers was an urgent political one in a contemporary sense. I had come through not only the wider women's movement in the 
UK (of which I had developed a whole critique because they wouldn't take the question of imperialism seriously), but also the black women's movement, where the term "black" was a sign used to mobilize an alliance between women of Caribbean descent and Southeast Asian descent primarily. $\underline{12}$ Coming together under that label "black" was a completely different use of the term than here, so I knew that essentialist preconceptions were not gonna get you very far. Even though we had distinct communities, it was that common experience of racism that [allowed us to] politically ally to oppose that oppression. And we had to do an awful lot of work, particularly in terms of fighting the imprisonment and the oppression that young black people were facing from the police. Because in the UK that was articulated purely in male terms. The women who were being arrested and bullied and facing all this racist oppression were rendered invisible. So we had that work to do there. In a way, I'd already developed a critique the feminist movement in general, the possibilities of black feminist movement, and how you actually organized to make black women visible. They were being as equally oppressed as men, but because of the political formation, it was only the young black men that were appearing.

Now structurally, just at an abstract level, there was the same thing happening with uncovering the history of enslavement. So that sense of "How are black women organizing?"- these were questions I already knew to look for. Or, "What was at stake in thinking about the questions that rendered the women invisible when they were also being subordinate?" And it was clear that one of these questions was the question of rape, and how that also was being buried. And also that the discourse of imperiled black masculinity was being mobilized here [in the US] in completely distinct ways from the political formation of the UK. So I already could see the way that was working, and it had obviously a lot to do with the civil rights movement, but there was a consistency about giving prominence to imperiled black masculinity.

If you look to works like Du Bois, he completely authenticated that, because [according to him] it was black women that had betrayed black men. $\underline{13}$ So I had a framework that I could apply to dismantle, or to bring questions to, a very different political formation. It was more like a way of seeing a framework that had been formed by a very different place, but that also reassured me that actually, yes, indeed, race is not transhistorical and isn't transnational. And it really is historically produced. So it was that move between understanding what was at stake in the contemporary moment of doing this work, in which imperiled black masculinity was still the most prominent mobilizing discourse, and then tracing that emergence historically. But also from the question of "What's at stake for this particular moment?" and understanding that. And I think that 
you can see those sorts of questions follow through in the work of some of my students. Francoise Hamlin, who did all that work on thinking about the civil rights movement, which is just dominated by these great black men. $\underline{14}$ And then she goes into all the beauty parlors and understands actually how that movement is really not only being built, but being run day by day in these spaces in which women are dominantchurches or whatever. But they're not visible in that final narrative, and yet, without all that work, that whole [civil rights] movement could not have existed.

Prince: Right. In a different sense, when they are visible, like when you're talking about Miles Davis and that question of whether or not we can separate the genius of the man from his violence toward women. $\underline{15}$ It's-

Carby: No.

Prince: Right.

[Laughter]

Carby: It's okay. That's an easy question.

Prince: I'm curious what you think about "cancel culture" as a response to saying, "I'm not going to separate Miles Davis from his violence towards women. Instead I'm going to cancel him."

Carby: I'm sorry. What's cancel culture?

Prince: Cancel culture is this sort of impulse that people have to "cancel" a celebrity. It's more than being critical-it's almost like an erasure.

Jerome Dent: For example, a few years ago, bell hooks called Beyoncé a terrorist. $\underline{16}$ And people decided that bell hooks and all of her work should be "canceled"-basically not taught anymore.

Carby: If it's really what I think it is, and I'm not sure I do, then my answer is: no. We should actually understand what makes her do that, frankly. You actually need to understand how this is working. The canceling is...It's too easy. You need to actually critically engage. I mean it's not like switching off a light. Right? You need to understand what has produced that. Obviously criticize it, but it seems that, if I understand it correctly, the concept of canceling is not critically engaging in the historical moment in which that happens, and it is not asking why on Earth it would have happened. So I think it's a symptom of the shallow thinking of social media. I 
mean, it's imagining that you can mount any sort of critical argument in a tweet. So I think the form and the media in which this is circulating is determining this response, which is not really a critical, carefully thought through, political response. It's a gesture. It's just a gesture. So you're left with a gesture. And what does that mean?

Dent: That makes me think about the R. Kelly documentary. $\underline{17}$ Under the idea of cancel culture, people are canceling R. Kelly. But he has a history of this kind of violence that has been well-documented for years. Does the idea of canceling a celebrity change when so much material is readily available? Are we allowed to throw the baby out with the bathwater, so to speak, once it's been so well-documented?

Carby: I'm trying to think of a historical context for this or even an analogous example, so let me know if I'm going on the wrong track here, but when you said "throwing the baby out with the bathwater," is it equivalent to sitting in a seminar where as a professor you're teaching Richard Wright's Native Son-as I have-and these very smart young black women in the course take a scene of violence against a woman in that novel and say, "So we shouldn't be reading that novel and we shouldn't have anything to do with Richard Wright anymore because this is unacceptable." Which it is. And "This is violence against women." Which it is. But do you then in fact say this book should never be on any more syllabuses, and we should never read Richard Wright anymore because it invalidates all of his work? Is that analogous?

Dent: Yeah.

Carby: So it's not, then, that canceling is in fact anything new, right? It's the way in which you're imagining that you can sort of voice an objection, which you should do, and identify what needs to be thought about very carefully. Because for a long time Richard Wright's work was not actually subject to any sort of gendered critique or a critique thinking about the real sexual politics of the moment in which he was writing. And how a writer can just accept the subordinate or can just take for granted the machinery of biopolitics in a way that will just dismiss women or be misogynistic or whatever. But it seems to me that you don't then just say, "We will never think again about Richard Wright," because I'm not sure where that actually leaves you. But you do try to tussle with him, right? And you do try to engage perspectives that you think are lacking. But just taking it and saying, "I'm not gonna think about that anymore and it shouldn't be on any syllabus,"-I don't think that is really engaging with what the problem is. 
Joel Burges: I've always wondered if these moments of wanting to remove something, whether it's Calhoun's name from a residential college at Yale, $\underline{18}$ or-

Carby: Which actually I support.

Burges: Right, of course. I was thinking that there are a bunch of different kinds of cultural and political processes behind each of these acts-the desire to remove a name or to stop reading something or not listen to something. And I guess what I always hear in this is a kind of discursive gesture, an overinvestment in what discourse can do. If we stop reading, and we stop talking about this, then it will go away. But the flip side of that seems to be a desire for a different set of social relations. So there's a particular kind of liberal fantasy about race that emerges there too, which isn't necessarily a different set of social relations, yet. But I've always wondered this, if the desire not to read Richard Wright anymore or the desire not to hear R. Kelly, that maybe it's about the desire for a different set of social relations. I'm curious if that sounds right to you or not.

Carby: So I suppose there are analogies in that you have a historical moment in which African American studies is trying to emerge, when it is actually trying to establish itself, and not just as a critique of the way in which other forms of knowledge have been organizing, which it should always be. And it is trying to remain committed to an interdisciplinary perspective that does not conform to the modes of the organization of knowledge that we already have. And in that moment of African American studies, basically the thrust is, "Well, we have our canon too." So you canonize and, in fact, most of the people who are being canonized are men. So people are saying, "We want Richard Wright in, and James Baldwin and all of these. This is our canon, and you, the English department, should be taking them seriously, too." So it seems to be putting in place a formation which is in fact, I would argue, as rigid as the one you are trying to get rid of. But then how do you rebel against that?

See with the Calhoun argument, the way to understand that [situation], is that you had this figure that a college was named after, and it rendered him visible actually when that college was named after that person, and it [rendered him visible by the] political movement that put that figure in place there. $\underline{19}$ You have to understand it as a movement of the Right at Yale, when these extremely conservative social historians and political historians of the South moved into Yale and actually sort of inventedreinvented-originary stories and put Calhoun's name on a college. It doesn't have anything to do with Calhoun at the time that he actually lived. This was actually about 
trying to construct what Yale was as an institution of learning, to reconstruct it in a particular moment in the 1920s into the '30s. So it's the way in which culture and history can completely reinvent itself. And understanding what the position of the people at that certain time and what their political investments were.

You know, I know one contemporary example: What is our political position when the Sacklers, [who own Purdue Pharma, which developed OxyContin], are putting millions of dollars into Yale? $\frac{20}{2}$ mean, do you name buildings after them? And Schwarzman, who is the right hand of Trump. $\underline{21}$ I mean, we now have a huge Schwarzman building. So how do you understand, how do you reveal what's politically at stake there? It doesn't seem that the canceling of the Schwarzmans or the canceling of the Sacklers is a phrase that really enables you to understand the political work of what is actually happening here when you say that you supposedly have an institution of learning, which is offering you critical perspectives on the past. So how do you actually maintain that constant engagement with the way in which history and institutions are inventing new originary stories for themselves?

Dent: Would you say then that in the emergence of African American studies when it was inventing its own canon, that this is a kind of disavowal or maybe refusal to deal with the messiness of political investments within certain cultural products but also certain institutions?

Carby: Right. Yes. And we need to unmess that. I mean that's part of the task is to think through how we are, in fact, implicated in that.

Dent: And cancel culture is refusal.

Carby: That takes me back to your question about Miles Davis. Because the key question there that I was also trying to raise was how, for many of us as black women, Miles Davis was an icon at particular moments in our lives through which we were experiencing ourselves as sort of sexual beings. So we were actually implicated through his music. There was that historical moment that we really needed to think about again. Not to just say it didn't happen. And I have not stopped playing Miles Davis's music, but I do understand in a different way what was at stake in him becoming this celebrity, because it's also a critique of celebrity. And celebrity formations. But there are [musical] phrases there that he will conjure and I can hear, even when I'm talking to you. But I do need to understand also what produced him and what he was as a person. [jokingly] I'm not canceling! I'm not going to destroy all my 
Miles! [laughter] And I hope that was clear, that we need to be conscious. That this is something we live and that we are politically implicated in.

Burges: And this seems to link to something that you said yesterday [in your lecture], which was "Know yourself as a historical subject."

Carby: As a historical subject. Yes.

Burges: I've also been thinking in this conversation a lot, because the last few days have been marked by a real push from you, and I think increasingly from us, to shift from a language of diversity to a language of antiracism.

Carby: Because diversity, it's the language of mystification. And actually not doing anything.

Burges: I was thinking, I'm even afraid of it becoming antiracist policy. And what I'm more interested in-

Carby: Practice.

Burges: Practice. Yeah.

Carby: If policies don't follow the practices, no. You can't just say this. You actually just can't put a whole series of words together in a line separated by commas. You know you can't just say diversity and whatever was that phrase. And inclusion and [...] equity, as if just pronouncing the sentence makes it okay.

Burges: Right. It's the flipside of cancel culture. It's a discursive performance rather than a practice.

Carby: Right. So you have to be committed to the practice, and understand all the dimensions of what an antiracist practice is. And then develop policies to support that, not the other way around. It's not a linguistic move. You know universities have been quite clever actually to take this language from the corporate world, but it's been about moving just pieces around on a board. It really hasn't changed the shape of the board. It's amazing how if you look at college catalogues, college catalogues have transformed. Colleges may not have [changed], but the college catalogues have people of color. It's like visible decoration. That's "visible diversity." It's worthless. Clever. With no use whatsoever. 
Burges: Do you feel like the university could actually ever truly become an antiracist space? I mean Jerome and I have talked about this. [jokingly] Do we need to burn it down? Or is it a matter of daily struggle?

Carby: It's a matter of daily struggle. It really is. You know, god, we've been fighting for graduate student unionization at Yale for how long? We haven't burnt it down yet. And we keep struggling. Even parking ourselves right outside the door of the president. So we keep making ourselves visible and the fight visible. But what would it do to burn Yale down? But you never, never give up the struggle. Even on the worst of days. And sometimes it's actually really difficult to remember, but it's that Gramscian phrase. "Pessimism of the intellect. But optimism of the will." $\underline{22}$ And it really is understanding that relation.

Burges: The optimism/pessimism?

Carby: No. Between the way in which white supremacy is back and incredibly more visible, not just here, but in Europe, in Brazil. So how do we think about where we are even historically? Are we actually back in those days with the rise of Mussolini? And what happened there? I mean, people didn't give up struggling. But we need to understand that what is happening is not just where we are localized. There are also wider issues, and a wider political formation, which we need to be drawing into this. And not be paralyzed by it. And not put aside the other work that needs to be done.

Jeffrey Tucker: I was just thinking, in terms of the wider formations that are happening at the moment in terms of "Make America Great Again," Brexit being a kind of "Make Britain Great Again," all of this seems to be tied to whiteness and to notions of whiteness. And I'm just curious as to what you think about the study of whiteness in the academy and where it has gone, how far it has gone, how far it needs to go. What is its significance in this particular moment?

Carby: We really need to bring the question of white supremacy back and make it very prominent in our conversations and in the structuring of our thought, because I think people became a little complacent thinking that we'd sort of won that. It went into the woods. It re-formed. And it's been decades in coming. It created all those new think tanks. There's been a lot of money behind it. But all those new think tanks came out with a whole new political charter for how to start to take over state governments and to reform the political landscape. All, of course, at a moment when people were "in fear" that the color of America was going to change, that white was not going to be the dominant formation anymore. So there's a whole long background there. 
They call it dark money now, but the Mercers and the Kochs have actually founded institutionally new intellectual formations that have been working for a long time to take over aspects of the government, which are now paying off in all sorts of ways. $\underline{23}$ So that's actually quite a long historical trajectory. And of course Brazil has its own history of fascism. $\underline{24} \mathrm{I}$ 'm always pushing back against people that thought there was never a history of fascism in the US. $\frac{25}{2}$ For many, fascism is something that happened in Europe. So we need to understand exactly why that is emerging. But who also are its allies? What is one of the first things that Bolsonaro is going after? $\underline{26}$ It's the Amazon. One of the first things that Trump said, "I'm gonna defend coal. We're gonna be drilling in the arctic. We're gonna be drilling in the national parks." And that's why a lot of what I'm doing now is not stuff about Imperial Intimacies, but is actually thinking about the environment and about ecology, and how we need to be taking that on in African American studies, and why we need to be linking to indigenous movements who are at the front of this.

You know. So I'm really not interested in burning Yale down. I'm much more interested in being supportive of the people who are on the front line of trying to save the planet. And it seems to me that we really have developed all sorts of important critiques of how you understand white supremacy, how you understand the political formations that it produces. How you understand bodies and forms of work, plantations, segregated cities, etc. We know how this works, so we actually have a whole critical apparatus that we can actually use if we combine with people who are working on the frontlines of the ecological battle. There's an awful lot at stake. And it's not gonna be just us who burn up. And it has everything to do with so much that we've been researching on and producing the thought and the critical apparatus of understanding what, not just race, but race with class, and gender, and sexuality have to do with all of this.

Dent: At the risk of being reductionist, I find in your work a gesture toward a capacious reading of "the alien other" that Butler is describing in the essay "The Monophobic Response"-an understanding, for example, in which the alien other can be embodied by the issue of climate change, which, in its global reach, represents a potential for a massive, paradigmatic shift in the social order. $\frac{27}{\mathrm{Am}} \mathrm{I}$ correct in this reading? And are there any cultural products, besides those produced by Butler, that do similar work in their capacity to draw our attention to these subjects, matters, or issues? 
Carby: Yes. Sylvia Winter is the theorist who tried to make us understand the urgency of understanding the contradictions which actually produce the humanism in northern Europe. Which now seems to dominate the way in which humanism is understood. Sylvia Winter was the one who said, we need to be taking that apart, and not taking humanism as given. Like we shouldn't take the American constitutionalism as given. What would be the consequences, then? Somebody like Saldaña-Portillo in Indian Given offers [a way] to think about the question of the Enlightenment from the perspective of southern Europe, not northern Europe. $\frac{28}{}$ Her work gives you a completely different understanding of, not only how to think much more critically about the environment, about the Enlightenment, but its consequences. For the whole of the Americas, as she looks at the racial geography of the US and the Americas as one, particularly the US and Mexico.

I have been teaching a lot about the eighteenth century on the one hand, and questions of futurity on the other, as the Enlightenment shapes our understanding of the world, and we shouldn't take it for granted. We really do need to be thinking back to how certain understandings of the human were put in place, which are completely limiting. They have limited the vision of all sorts of possibilities, as well as leading to what we know now as "the history." But if you actually go back, as Sylvia Winter and Saldaña-Portillo ask you to, then you can start to grasp that there were other possibilities of thinking about the human. And it seems to me that that's what people like Butler are doing.

To come back to American constitutionalism as an example: there was that moment where you could choose revolution or a constitution, and they choose constitution, and we all know what the result of that was. Yet if they had not opted for the constitution and had opted for revolution, we wouldn't have the Electoral College in place. That Electoral College is in place because they didn't trust people. They didn't trust the people's vote. We shouldn't be accepting the apparatus under which we are working. We shouldn't accept that constitutionality, because it happened at that certain point and was the only possibility for thinking about the organizations of our supposedly anticolonial state.

Tucker: This is what makes science fiction perhaps interesting to you, in that it's a genre in which the fundamental question is, "What if things were different? What if the structures with which we are familiar were different in their founding, in their institution?" 
Carby: Yes, and this is particularly important in education. How can we defamiliarize the students from the institutions? They think this is the world as it is. And therefore, somehow all that African American studies can offer is like an added ingredient. No, actually it's a completely different way of understanding historically what was possible and what could have been. And therefore, what we can imagine for the future. Because we're not shackling ourselves to this other system.

Dent: In your discussion of Butler's work, you state: "The genre labels science fiction and Afrofuturism are insufficient to capture Butler's exploration of degradation, violence, oppression and alternative modes of belonging." Considering her importance as a lauded figure in the field of Afrofuturism, I'm compelled by what I believe to be a call to see and read her and her work beyond the limitations of Afrofuturism. $\underline{29}$ You state that she "creates an alternative humanism, one that transcends what we understand to be humanity and shape-shifts us into the imaginative and political realization of species being that Sylvia Wynter advocates...This is a move far beyond what we have come to understand as Afrofuturism..."

As a follow-up to the question of the definition of Afrofuturism, could you describe/define the limitations you find to be present in the "work" of the field? Here I'm gesturing specifically toward the limitations you are describing, and the political, social, and/or epistemological iterations of these limitations?

Carby: One limitation is why only Afro? Why not futurism? Why not understand this work is speaking to a wider humanity? It is not just our purview. What is at stake is this wider understanding. I also have a sort of beef with some of the masculinity of Afrofuturism actually. Even while you're understanding how important groups like Drexciya were. $\underline{30}$ Of course, they are extraordinary in terms of the vision that they were producing and the way they were returning to understanding of what was in the oceans. They have had a huge influence on Ellen Gallagher's work, for example. Yet she has taken it into dimensions that move far beyond that. $\underline{31}$ But Drexciya were actually extremely masculine. Their visual culture is, for example, with the undersea warriors.

But if you put that up against NourbeSe Philip who wrote Zong! (2008), for example, and how she actually took the court declaration and account from the Zong court case and completely dismantled it. $\underline{32}$ To me, that gives it a completely different and far more liberatory way of thinking about what we need to do to dismantle these apparatuses of law, and of governance, of governmentality. 
I always remember a story of when I taught NourbeSe Philip for the first time with my graduate students. There was this graduate student who was going to New York and was going to read it on the journey down. She was standing on the New Haven Union Station platform, and she was reading it. And she was thinking, "I shouldn't be reading. I should actually be speaking it." And she actually started to speak it. She understood it another way. NourbeSe Philip is actually online reading different parts of her work. I played that for my students. This is just to say that it's not about Drexciya's recovery of black warriors, because we've just had enough of being victims. Yes we have, and victimage is not going to really provide all that we need to politically emancipate ourselves. What they were doing in Detroit where people didn't seem to have much hope was very important. But it's not about having male warriors now to save us. The imagination of that seems to me limited by its own sort of masculinity.

Where people are challenging us in a much wider way, is to rethink even how we are enunciating the possibilities of our own liberation, or the recovery of history, fragmentary as it may be. What is at stake is how do we re-assemble that?

We need to understand it in all the sort of possibilities of our being. And that is what I like about Ellen Gallagher's work because when you stand in front of her different pieces, they are always incredibly multilayered. She will layer with paper that has come from different historical moments, and then she will carve into it. As you are looking at it, there are multiple temporalities. And yet out of those temporalities are emerging other possibilities. Whereas, in her earlier work where she's using magazines, black magazines from the 30s and 40s... Or whether it is her more contemporary work, which is oceanic. There are really interesting visual possibilities. NourbeSe Philip is doing in language what Ellen Gallagher is doing with her art. It's asking us to dig into an understanding of these temporalities existing, but then to come out with creating completely new ways of seeing. Which I think was what Butler wants us to do.

Dent: I'm thinking about your talk about Kara Walker's Freedom. $\frac{33}{}$ Do you consider it as a critical fabulation? I am also looking at the work that Tavia Nyong'o has recently

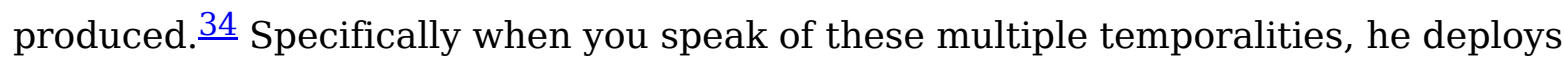
the term "angular sociality." He's speaking about the ways in which we could hold attention synchronically and diachronically at the same time. He is attempting to get us past an impasse he is identifying as being locked into an either/or situation. His understanding opens up a way of thinking through black time as such. According to you, is this a better way of understanding the work of Octavia Butler and Kara Walker? 
If we understood it under this category rather than trying to pigeon hole it under Afrofuturism?

Carby: Yes, I think so. Because it is bigger than Afrofuturism. And because-what is at stake is that constant movement between pastness and futurity. It's not just futurity. But it's actually that constant movement of temporalities between them. Where pastness has futurity at stake in it. And understanding pastness is always from a point of view of interest, right? Not just what happened but what was said to have happened. And how we sort of unravel that. So yes, I think with Kara Walker it makes you extremely uncomfortable and is quite extraordinary at the same time. It is true that it ends with a figure stepping off into what is possibly the abyss. Whereas Octavia Butler isn't offering you an abyss. And I don't think Ellen Gallagher is either. Or even Samuel Delaney. $\underline{35}$ They are offering you a different way of thinking about temporality, which always has at stake the possible or the emancipatory or the liberatory. And even though the figure in Freedom is constantly fighting for the liberation, that's actually not what she discovers. It's not what she reaches. In Freedom it is still trapped in the fight for it.

Freedom is very, very tortured. It is incredibly disruptive. I can't imagine what those rich people thought when they opened it up. $\frac{36}{16}$ is supposedly a child's book, which is also a wonderful, in-your-face gesture. And there is something seventeenth, eighteenth century about it. You cannot actually climb out from under your patron any more than her daughter could climb out from under her owner who's abusing her. It is a very difficult piece, extremely complex and very rich. The daughter would rather die than continue in that, which evokes what was at stake in enslavement. That I would rather die than continue this. There is this other way of being in Butler, which I don't think Kara Walker has yet. And I'm really interested to see what Claudia Rankine does with this whiteness stuff, 'cause I think that may be much more liberatory. But I don't have a good grasp of what she is doing yet, of all the implications of her work.

Patrick Sullivan: There is a concern in your work, about biography, or what you call in Imperial Intimacies, life writing and auto-history. What did the biographical do for you in Imperial Intimacies?

Carby: Life writing has been incredibly important historically. For me, it's actually not just the slave narrative. It is returning to the possibilities of what Equiano was trying

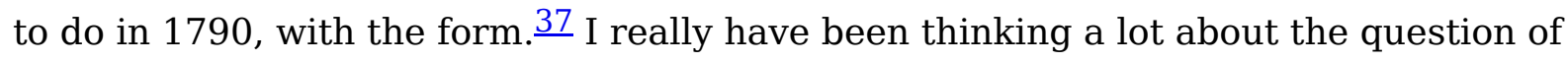
form lately. There is the question of life writing, but then there is the question of the 
way in which the genre of the autobiography or conventional ways of imaging life writing or auto-history have not been able to account for black lives, frankly. Equiano opened up multiple possibilities when he said, "I am British, and I am African, and I have been enslaved." He deforms and creates a new possibility of form out of life writing, and this isn't Benjamin Franklin, who can just say, "I am." $\underline{38}$ Nobody was able to take that "I" and that's why it starts with "Where am I from?" This is the question that none of us have been able to take for granted in expressing the complexity of becoming and being through literary form.

So I'm thinking that we need to be about the work of deformation, as well as trying to find more experimental ways. I am not pretending that I have found or created a whole other genre here. This is more about putting in place a set of questioning, that even Equiano was asking, in terms that the British have never taken seriously. He was offering a way of being - of transnational being and becoming - that the parochial colonial situation he was within has never understood, has never really been able to place. There are profound dimensions of how to understand the life within imperialism. It has never transformed the possibilities of what people understand by being British. It is really trying to say from the literary perspective that we really need to be quite disruptive of conventional ways of understanding how people write lives.

And so I chose those two perspectives: one from Gramsci, that we need to understand our constitution as historical subjects, and the Stuart Hall perspective, that identity is in the future to be created not just in the past to be recovered. $\frac{39}{1 t}$ profoundly questions notions of biography and autobiography. Which if you think about it, the genres are overwhelmingly dominated by the nation. The boundaries of national thinking. And we can't do that. We should be questioning that.

Then to make the story possible, it was really important to anchor it. I hope that by doing that sort of investigation, people will think of [Imperial Intimacies] as about dismantling what we think of by family, because that can actually be quite oppressive as an institution, and think about the familial in a way that anchors it in a much wider history. So the fact that I come from people who are on two sides of the Atlantic, both of them imperial subjects, enabled me to say something, I hope, larger about the way in which the imperial metropole is intimately entangled with its colonies, plural, through a particular colony. And particular histories. But I hope people don't just see it as being about only the individual story. 
Within that I was trying to disrupt certain patterns of thinking about these wider questions, not just of imperialism but of what enslavement is; that it is not just the story of the big sugar barons and the aristocrats. In Britain a lot of people, really good people, are doing work trying to uncover the history of the implication of Britain and the way in which it profited from enslavement. Art historians, for example, have spent a lot of time going into aristocrats houses and finding paintings with their black enslaved people in them and stuff like that. But I am also really about the work that says, "This is about the ordinary every day." Because people think, "Well, that was the aristocrats. That has nothing to do with me. I didn't profit from enslavement." Actually: wrong. Your entire family did even if you were poor. It is a definite shift. That's the point about rediscovering this story of someone who actually came from the son of a carpenter, but because of enclosure, could never actually be that artisan. Because their enclosure actually freed up a ton of young men that could be taken not only into the local militia but then into an army to fight the revolutionary or Napoleonic wars, which are about colonialism. They were all struggling. They were all fighting over these colonies and resources and peoples. An infantry soldier could be transformed into a slave owner actually amazingly easily. Because he can be incorporated as this white person. And then what power that gives this person who comes from very modest means.

My mother grew up in a tiny hamlet-a geographical unit too small to be a village. In that hamlet where she grew up in the 20s and 30s, if you dig into its history, a landowner in that area, [Sir John] Popham, actually financed the first colonial expeditions to the Americas. $\underline{40}$ There is still a Popham Park in Maine. There were two expeditions, one to the north and one to the south. We tend to know more about the Virginia Company. But Popham actually financed an expedition even earlier than that, which went to Maine and was a failed colonization. The point is, this is a tiny little hamlet, but if you actually research its history there was Popham who actually became chancellor to Elizabeth I and became a judge, and he ripped off people royally. They are all a bunch of criminals. And then his son led this expedition, and they were also really into piracy and all. They are people that I am related to, but they could be coat hangers for this bigger story. That's the intimacy. It is layered, it is temporal, and it is about encounters between individuals and also between the imperial metropole. The people that colonized and enslaved. I hope people think about it as a genre larger than autobiography, which centers the individual life. But that question-“Where are you from?"-we've been asking for a very long time. 
Sullivan: There is another word you have persistently used throughout the events, and which also came up during our reading group, which is contradiction. I was wondering, with Jerome's question about the pastness and futurity, what does contradiction do for you?

Carby: It is a key term in Marxist thought, and I use it a lot with students because they

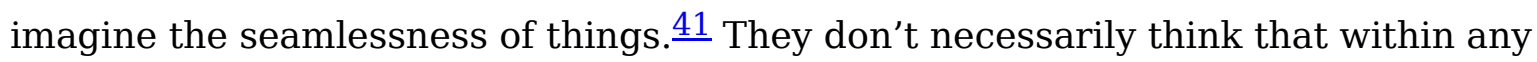
system of oppression, it has created the seeds of its own destruction. That's really what contradiction is. For example, if you are thinking about the imposition of laws by the Jamaica Assembly over the movement of the enslaved, the imposition of all the attempts to limit their movement actually grew it. Within that, people are breaking those boundaries all the time as you're trying to impose them. The heart of contradiction is for example when Michel-Rolph Trouillot refers to the fact that the Haitian revolution was an impossibility for the dominant imagination. The dominant imagination was so concerned with the imposition of the maintenance of a system that they could not imagine that system could in fact be completely overturned. And can we always keep that sort of dialectical relation in our own work to think also about impossibility. The possible within the seemingly impossible. Is it really that different? "Pessimism of the intellect and optimism of the will." It comes from a Marxist concept originally, but it really is about how you see the relation between subordination and refusal. I don't think my students always do. I think they get depressed and pacified by the seeming untouchability and omnipotence of a system coming down from above. And they don't think about how that always is generating its opposite. Because without that, there is no hope or empathy. Because there is no imagination of it.

\section{Footnotes}

1. Hazel V. Carby, Imperial Intimacies: A Tale of Two Islands (London: Verso, 2019). Published by Oxford University Press in 1987, Reconstructing Womanhood: The Emergence of the Afro-American Woman Novelist is Carby's landmark analysis of the texts written by black women in the nineteenth and twentieth centuries. These authors include Frances Ellen Watkins Harper, Pauline Elizabeth Hopkins, Ida B. Wells, and Anna Julia Cooper. Based upon her doctoral dissertation, Reconstructing Womanhood considers how these narratives relate to the historical category of womanhood and the social environment in which it emerged. Of particular importance to Carby's text are the narratives of enslaved women and their relation to the construction of sexual categories. $\_$ 
2. Founded by Richard Hoggart in 1964, the Centre for Contemporary Cultural Studies was a research center at the University of Birmingham, England that greatly influenced the development of cultural studies until its closure in 2002. The Centre is especially known for its time under the directorship of Stuart Hall. From 1969 to 1979, Hall taught a generation of scholars who would each serve as important contributors to the field of cultural studies. These affiliates include Michael Denning, Richard Deyer, Paul Gilroy, Angela McRobbie, and Hazel V. Carby. $\bullet$ 3. Charles T. Davis (1918-1981) was a literary scholar who majorly influenced the discipline of African American Studies in the US. He served as the chairman of AfroAmerican Studies at Yale University until his death. His books include the edited volumes Black Is the Color of the Cosmos: Essays on Afro-American Literature and Culture, 1942-1981 (Howard University Press, 1989) and, with Henry Louis Gates, Jr., the edited volume The Slave's Narrative (Oxford University Press, 1991). $€$ 4. John Blassingname (1940-2000) was an influential historian of American slavery and served as the chairman of African-American Studies at Yale University for several tenures. His books include the edited volume New Perspectives on Black Studies (University of Illinois Press, 1971), The Slave Community: Plantation Life in the Antebellum South (Oxford University Press, 1972), and Black New Orleans, 18601880 (University of Chicago Press, 1973). Robert Stepto is the John M. Schiff Professor of English, Professor of African American Studies, and Professor of American Studies Emeritus at Yale University. His books include From Behind the Veil: A Study of Afro-American Narrative (University of Illinois Press, 1991), Blue As the Lake: A Personal Geography (Beacon Press, 1998), and A Home Elsewhere: Reading African American Classics in the Age of Obama (Harvard University Press, 2010).

5. Henry Louis "Skip" Gates Jr. is the Alphonse Fletcher University Professor and Director of the Hutchins Center for African and African American at Harvard University. He is the author of many influential publications, including The Signifying Monkey (Oxford University Press, 1988). In this major text, Gates studies the literary and aesthetic practice of "signifyin'" within the work of African-American authors. He is also renowned for his work in documentary film work that covers AfricanAmerican history. In 2013's widely-acclaimed docuseries The African Americans: Many Rivers to Cross covers the broad history of African American history up to the presidency of Barack Obama. Gates served as host, writer, and executive producer 
for the project, and received several accolades for his work, including an Emmy and a Peabody Award. $ヒ$

6. Margaret "Maggie" Thatcher (1925-2013) was the Prime Minister of the United Kingdom from 1979 to 1990 and led the Conservative Party from 1975 to 1990. Thatcher was vocally xenophobic, propagating the belief that immigration was a threat to the UK. $\doteq$

7. Isaac Julien (b. 1960) is a renowned filmmaker and installation artist whose work is known for its reimagining of historical black figures such as Langston Hughes, Frederick Douglass, and Frantz Fanon. $\_$

8. Black British cultural studies has been thought of as either a companion or competitor to dominant methodologies of African American Studies in American universities. In addition to considering the specific context of blackness in England, black British cultural studies also offers alternatives to theories of blackness that have historically been determined with American contexts. See Houston A. Baker Jr., Manthia Diawara, and Ruth H. Lindebord, eds., Black British Cultural Studies: A Reader (Chicago: The University of Chicago Press, 1996). $\doteq$ 9. At the 1893 World's Columbian Exposition in Chicago, Frances Harper, Fannie Barrier Williams, Anna Julia Cooper, Fannie Jackson Coppin, Sarah J. Early, and Hallie Quinn Brown, all black women, addressed the delegates of the Exposition on the need for the progression of women's rights to also include black women. See Hazel V. Carby Reconstructing Womanhood: The Emergence of the Afro-American Woman Novelist (Oxford: Oxford University Press, 1987), 3-6.

10. For more on Carby's analysis of blues, see Hazel V. Carby "Women, Migration, and the Formation of a Blues Culture" in Cultures in Babylon: Black Britain and African America (London: Verso, 1999), 7-63. 11. For example, see Robert Palmer, Deep Blues: A Musical and Cultural History of the Mississippi Delta (London: Penguin Books, 1982).

12. During the 1970s and 1980s, the women's movement in the United Kingdom helped create historical legislation, including the Sex Discrimination Act of 1975. With this act, discrimination of one's sex or marital status was outlawed in several matters including employment and education. However, as Carby addresses in her essay "White Woman Listen! Black Feminism and the Boundaries of Sisterhood," the progression of women's legal rights in the United Kingdom was negligent of how it 
benefited from imperialism. The result was an uneven distribution of protection of women whereby white women benefited from the discrimination and maltreatment of black people. See Hazel V. Carby "White Woman Listen! Black Feminism and the Boundaries of Sisterhood" in The Empire Strikes Back: Race and Racism in Seventies Britain (London: Hutchinson, 1982), 212-235. 13. See W.E.B. Du Bois "The Damnation of Women” in Darkwater: Voices From Within The Veil (Mineola: Dover Publications, 1999), 95-108. Also see Hazel V. Carby, Race Men (Cambridge: Harvard University Press, 2000).

14. See Francoise Hamlin, Crossroads at Clarksdale: The Black Freedom Struggle in the Mississippi Delta after World War II (Chapel Hill: The University of North Carolina Press, 2012). $\subseteq$

15. Miles's wife, Frances Davis, recalls "running for [her] life, more than once" as a result of his spousal abuse. See Pat H. Boeske, "Grappling With the Cool and Rage of Miles Davis," New York Times, November 21, 2006, https://www.nytimes.com/2006/11/21/arts/21iht-miles.3611591.html. $\leftrightarrows$ 16. See bell hooks "Moving Beyond Pain," bell hooks Institute, May 9, 2016, http://www.bellhooksinstitute.com/blog/2016/5/9/moving-beyond-pain. 17. Surviving R. Kelly, directed by Nigel Bellis and Astral Finnie (New York: Lifetime, 2019). $\subseteq$

18. In February 2017, Yale announced that Calhoun College's name would change to Hopper College. The former name honored John C. Calhoun, a prominent advocate for and defender of slavery and a forefather of the Civil War. The new name celebrates Grace Murray Hopper, a computer pioneer and naval officer. See Andy Newman and Vivian Wang "Calhoun Who? Yale Drops Name of Slavery Advocate for Computer Pioneer," New York Times, September 3, 2017, https://www.nytimes.com/2017/09/03/nyregion/yale-calhoun-college-gracehopper.html. $\doteq$

19. Calhoun College's naming in 1933 signals persistent and institutional protection of white supremacy. R. Owen Williams writes: “In 1933-exactly 100 years after Senator Calhoun led his native South Carolina through the Nullification Crisis-Yale received an extraordinarily large donation of \$20 million from Edward S. Harkness (which, according to the U.S. Bureau of Labor Statistics, would be worth over $\$ 360$ million today), enabling the university to construct seven dormitory clusters...A 
special 'nomenclature committee' deliberated for more than a year as to who should be honored in the naming of these colleges. From 230 years of graduates, Yale selected only two: Jonathan Edwards and John C. Calhoun." The selection of Calhoun corresponds with 1930s American culture, which Williams recounts: "A distorted image of blacks based on a song-and-dance routine, 'Jumpin' Jim Crow,' became synonymous with a codified system intended to segregate the races. Worse, not only did popular literature, minstrel acts, and vaudeville shows represent blacks as buffoons, films like Birth of a Nation incited whites to vigilantism. Membership in the $\mathrm{Ku}$ Klux Klan soared in the 1920s and remained strong until the Great Depression. Lynch mobs killed thousands of blacks." See R. Owen Williams, "The Danger of Erasing Yale's Confederate Ties," The Atlantic, October 7, 2015, https://www.theatlantic.com/politics/archive/2015/10/yale-calhoun-collegeconfederate-tie/409246/. $匚$

20. The Sacklers are an American and British family who accumulated their immense wealth in the pharmaceutical industry. The family has provided immense endowments to many art institutions such as the Guggenheim Museum in New York City. Their contribution to the American opioid crisis has placed them under immense scrutiny and criticism by activists and artists alike. $\bullet$

21. Stephen A. Schwarzman, the chief executive of Blackstone, is "one of the president's most respected and reliable allies in high finance," providing Trump with advice on trade and the economy. As a consequence of Schwarzman's relationship with Trump, Blackstone has secured management of prominent multi-billion dollar funds across the globe. See Jessica Silver-Greenberg, "The Benefits of Standing by the President," New York Times, August 19,

2017, https://www.nytimes.com/2017/08/19/business/the-benefits-of-standing-by-thepresident.html. $\triangleq$

22. Antonio Gramsci (1891-1937) was an Italian political theorist and Marxist philosopher. In Letters from Prison, Gramsci's December 19, 1929 letter includes the following statement: "I'm a pessimist because of intelligence, but an optimist because of will." Gramsci likely borrowed the phrase from Romain Rolland (18661944) who used "pessimism of the intelligence, optimism of the will," in 1920. See Antonio Gramsci, Letters from Prison (New York: Columbia University Press, 1994), 299-300.

23. Robert Mercer, a hedge-fund manager known for funding rightwing political projects and launching Trump's presidency, is the C.E.O. of Renaissance 
Technologies. His daughter, Rebekah Mercer, supervises the Mercer Family Foundation, which gives millions of dollars to ultraconservative groups. Mercer adopted the strategy of Charles and David Koch, billionaire libertarians and owners of the Koch Industries conglomerate. By 2011, the Mercers and Koch Industries worked together; in 2014, Mercer contributed \$2.5 million to the Koch's Freedom Partner Action Fund. See Jane Mayer, "The Reclusive Hedge-Fund Tycoon Behind the Trump Presidency," New York Times, March 17, 2017, https://www.newyorker.com/magazine/2017/03/27/the-reclusive-hedge-fundtycoon-behind-the-trump-presidency. $\doteq$

24. Plinio Salgado (1895-1975) founded Brazialian Integralist Action in 1932. That year, Manifesto de Outubro was published, calling for a great fascist movement based on conservatism, nationalism, and authoritarianism. Integralists occupied a range of authority roles from 1964-1985 after a 1964 coup led to a military rightwing dictatorship. See Bertonha, Joao, "The Brazilian radical right in the twentieth century: from Monarchism and Nationalists Leagues to Fascism and the military dictatorship (1889-2011)" Studia Historica. Historia Contemporánea 30 (2012). 25. "Key historical and institutional dynamics in the United States have persistently facilitated the emergence of fascist and fascistoid groups. The country has its own cult of the warrior fueled by a history of frontier violence, empire building, and since the Cold War, vast outlays of military spending that have helped to create a permanently militarized culture. Add the venerable racialized dual system of liberalism and a surprisingly tenacious streak of anticommunism to which the American warrior cult is linked, and you have very real foundations for would-be fascists to build on as their relative social privileges become threatened. Consequently, in the United States, as in Europe, there are actors on the political stage who represent neofascist functional equivalents, and they have shifted the political center at a number of critical junctures." Christopher Vials, Haunted by Hitler: Liberals, the Left, and the Fight against Fascism in the United States (Amherst: University of Massachusetts Press, 2014), 21-22. 26. Jair Bolsonaro (b. 1955) is a former member of the conservative Social Liberal Party, and has been the 38th president of Brazil since January, 2019. His political views have been characterized nationalist, populist, and far-right. $\triangleq$ 27. Octavia Estelle Butler (1947-2006) was a successful American science fiction and fantasy writer. In her short 1995 essay "The Monophobic Response" she considers the tension between "our ongoing eagerness to create aliens" and " our inability\} to 
get along with those aliens closest to ourselves, those aliens who are, of course, ourselves." The piece concludes: "Perhaps someday \{humanity $\}$ will have truly alien company. Perhaps we will eventually communicate with other life elsewhere in the universe, or at least become aware of other life, distant, but real, existing with or without our believe, with or without our permission. How will we be able to endure such a slight? \{...\} Perhaps for a moment-only a moment-this affront will bring us together, all human, and much more alike than different, much more alike than is good for our prickly pride. Humanity, 'E pluribus unum' at last, a oneness focused on, and in a sense, fertilized by the certain knowledge of alien others. What will be born, then, of such a strange and ironic union?" Octavia Butler, "The Monophobic Response," in Dark Matter: a Century of Speculative Fiction From the African Diaspora, ed. Sheree R. Thomas (New York City: Warner Books, 2000), 415-416. 28. María Josefina Saldaña-Portillo is a professor of social and cultural analysis at New York University. Her areas of research include Latin American and Latinx studies, Indigenous studies, colonization and comparative race in the Americas, globalization and immigrations studies, development studies and revolutionary thought, and hemispheric literary and cultural studies. Duke University Press published her book Indian Given in 2016.

29. Daylanne K. English describes Afrofuturism as such: "Afrofuturism refers to a flourishing contemporary movement of African American, African, and Black diasporic writers, artists, musicians, and theorists. Afrofuturism comprises cultural production and scholarly thought-literature, visual art, photography, film, multimedia art, performance art, music, and theory-that imagine greater justice and a freer expression of black subjectivity in the future or in alternative places, times, or realities." Daylanne K. English, "Afrofuturism” in Oxford Bibliographies: Literary and Critical Theory, last modified July 26, 2017, https://www.oxfordbibliographies.com/view/document/obo9780190221911/obo-9780190221911-0004.xml..

30. Drexciya is an electronic music duo from Detroit consisting of James Stinson and Gerald Donald. They created a mythology of an underwater Drexciyan race descended from African women thrown overboard on the Middle Passage. See Nettrice Gaskins, “Deep Sea Dwellers: Drexciya and the Sonic Third Space” Shima: The International Journal of Research into Island Cultures 10 no. 2 (2016): 6880, https://doi.org/10.21463/shima.10.2.08. 
31. Ellen Gallagher (b. 1965) is a contemporary American artist known for multimedia paintings, works on paper, and video art. Some of her work repurposes advertisements from popular magazines, transforming images via repetition, abstraction, and accumulation. $\subseteq$

32. M. NoubeSe Philip (b. 1947) is a Tobagonian-Canadian author known for her poetry, plays, novels, and non-fiction. Her collections of poetry include Thorns (1980), Salmon Courage (1983), She Tries Her Tongue (1989), Her Silence Softly Breaks (1988), and Zong! (2008). More information is available on her website: https://www.nourbese.com/. Zong! is about the legal decision resulting from Gregson v. Gilbert (1783) regarding the Zong massacre, a mass murder of over 130 African slaves aboard a British slave ship. The ruling sided with the Gregson slavetrading syndicate, declaring that deliberate killing of slaves in order to claim insurance money was legal. $\subseteq$

33. Kara Walker (b. 1969) is contemporary American artist who is known for her large silhouette and sculptural works that critically reimagine and represent narratives of black life and history. $\leftrightarrows$ 34. Tavia Nyong'o is Professor of African American Studies, American Studies, and Theater and Performance Studies at Yale University. His book Afro-Fabulations: The Queer Drama of Black Life (NYU Press, 2018) articulate a theory of fabulation within black queer cultural and artistic practices. $\subseteq$

35. Samuel R. Delany (b. 1942) is an American novelist and cultural critic known for his science fiction and fantasy. His works include Babel-17 (1966), The Einstein Intersection (1967), and Dark Reflections (2007). $\bullet$

36. Freedom, a Fable (1997) is a pop-up book by Walker featuring her signature paper cut-out silhouettes. The short story content-about an emancipated slave who remains oppressed-is based on literary memoirs of former slaves and novels like Uncle Tom's Cabin. The book was commissioned by the Peter Norton family for their Peter Norton Christmas Project. Norton, a software entrepreneur and art collector, commissions an art edition every year to celebrate the Christmas season. $\triangleq$ 37. Olaudah Equiano (c. 1745-1797) was a Nigerian-American writer and abolitionist. Sold into slavery as a child, he purchased his freedom in 1766 and was active in anti-slave trade movements. He is known for his autobiography, The Interesting Narrative of the Life of Olaudah Equiano (1789). See Hazel V. Carby “Becoming Modern 
Racialized Subjects: Detours Through Our Pasts to Produce Ourselves Anew," Cultural Studies 23, no. 4 (2009): 624-657.

38. Benjamin Franklin (1706-1790) was a Founding Father of the United States and a major figure of the American Enlightenment. $\doteq$

39. Stuart Hall (1932-2014) was a British-Jamaican cultural theorist and political activist. As a founder of the New Left Review and pioneering scholar in race and gender studies, his work provided the basis for British cultural studies. His works include Deviancy, Politics and the Media (1971), Encoding and Decoding in the Television Discourse (1973), Resistance Through Rituals: Youth Subcultures in PostWar Britain (1976), and Representation: Cultural Representations and Signifying Practices (1997).

40. Sir John Popham (1531-1607) acted as Lord Chief Justice of England and a private counsellor to Queen Elizabeth. $\leftrightarrows$

41. Marx's dialectical materialism explains social dynamics through an interplay of contradictions. "What constitutes dialectical movement is the coexistence of two contradictory sides, their conflict and their fusion into a new category." See Lawrence Crocker, "Marx's Use of Contradiction," Philosophy and Phenomenological Research 40, no. 4 (1980): 558-63. 